\title{
Academic Freedom Issues for Academic Librarians
}

\author{
Richard A. Danner \\ Barbara Bintliff
}

\begin{abstract}
Professors Danner and Bintliff argue that understanding academic freedom and faculty tenure is important for academic librarians, both to gain better perspective on the concerns of faculty researchers and teachers, and to highlight matters of common concern to librarians and faculty. The authors discuss the basic tenets of academic freedom and tenure, then compare academic freedom with the intellectual freedom concerns of librarians. The article concludes by introducing several current issues of importance to librarians, faculty, and everyone concerned with academic freedom on university campuses. doi:10.1300/J113v25n04_03 [Article copies available for a fee from The Haworth Document Delivery Service: 1-800-HAWORTH. E-mail address: <docdelivery@haworthpress.com> Website: <http://www.HaworthPress.com>]
\end{abstract}

KEYWORDS. Academic freedom, faculty tenure, librarians' tenure, law school administration

Richard A. Danner is Rufty Research Professor of Law and Senior Associate Dean for Information Services, Duke University School of Law.

Barbara Bintliff is Nicholas Rosenbaum Professor of Law and Director of the Law Library, University of Colorado at Boulder School of Law.

Professor Richard A. Danner wishes to thank Laura Scott, Lecturing Fellow, Duke University School of Law, for her excellent work in gathering information for this article.

This article is based on papers prepared for the program: "Exploring Uncharted Territory: The Culture and Context of the University," presented at the 100th Annual Meeting of the American Association of Law Libraries, Saint Louis, MO, July 9, 2006. (C) 2006 by Richard A. Danner and Barbara Bintliff.

Legal Reference Services Quarterly, Vol. 25(4) 2006

Available online at http://lrsq.haworthpress.com doi:10.1300/J113v25n04_03 


\section{INTRODUCTION}

What do the concepts of academic freedom and tenure mean to faculty and other members of a university community? Why do they exist and what are the ramifications of how they are applied on a university campus? Such questions may not be on the radar screens of most academic librarians until a major academic freedom issue breaks into the national news and prompts reactions from outside interest groups, university governing boards, state legislatures, and the public. ${ }^{1}$ Academic freedom is especially important for librarians who have faculty status. But, understanding the background of academic freedom and tenure will provide all librarians working in academic libraries better perspective on the responsibilities and concerns of faculty members.

In this essay, we present the background and basic principles of academic freedom, discuss its relationship to faculty tenure, and compare academic freedom with the traditional intellectual freedom concerns of librarians. Finally, we note several areas of current interest that should be of concern to librarians as well as to professors and others concerned with academic freedom issues on university campuses.

\section{ACADEMIC FREEDOM}

Academic freedom is an essential ingredient in the development and maintenance of a strong educational community. The American Association of University Professors' (AAUP) Statement of Principles on Academic Freedom and Tenure, promulgated in $1940,{ }^{2}$ discusses academic freedom as it applies within institutions of higher learning in three areas: research, teaching, and extramural speech. ${ }^{3}$

The essence of the AAUP statement is as follows:

Institutions of higher education are conducted for the common good and not to further the interest of either the individual teacher or the institution as a whole. The common good depends upon the free search for truth and its free exposition. ... Freedom in research is fundamental to the advancement of truth. Academic freedom in its teaching aspect is fundamental for the protection of the rights of the teacher in teaching and of the student to freedom in learning. It carries with it duties correlative with rights. ${ }^{4}$

Academic freedom can be defined as the atmosphere of free inquiry and discussion necessary to find and teach "truth" as the faculty member 
sees it. "It is the freedom to research any topic and to report one's findings without fear of retribution. Academic freedom enables our researchers to investigate the unpopular and the unpalatable, to state their findings without fear or favour." 5 Without academic freedom, faculty would be harder pressed to make discoveries, question existing practices, expand fields of knowledge, and communicate findings to students and others. Similarly, students might be thwarted in their abilities to question, to explore, to muse aloud, or to engage in critical thinking.

A key to understanding academic freedom is the fact that academic freedom is not an inherent right for faculty and others seeking its benefits and protections at institutions of higher learning. It is actually a privilege, granted by individual universities. Each university defines academic freedom for its campus, making it essential for faculty members and others to understand how the privilege is applied at their home institution. While it is typical for universities to adopt the AAUP's definition of academic freedom, sometimes almost verbatim, it is not unusual for schools to apply their own definitions, sometimes taking into consideration "religious or other aims of the institution."6 This is anticipated in the AAUP Statement, which states, "Limitations of academic freedom because of religious or other aims of the institution should be clearly stated in writing at the time of [a teacher's] appointment."7

As a privilege, academic freedom comes with limitations, chief among them the requirements that faculty members must maintain competence in their fields; exert themselves to the limit of their intellectual capacities in scholarship, research, writing, and speaking; and "act on and off the campus with integrity and in accordance with the highest standards of their profession." 8

Universities often specify in their grant of academic freedom that faculty members should be careful not to introduce into teaching controversial matters that have no relation to the subject of the class. ${ }^{9}$ Typically, faculty members are admonished to refrain from conduct disruptive of university functions; from injury to persons or damage to property on the campus; and from impeding freedom of movement of students, school officials, employees, and invited guests to the university. ${ }^{10}$ Universities do not view these kinds of activities as being within academic freedom's pursuit of "truth."

A widespread restriction on academic freedom relates to research on human beings, which comes into play in the form of oversight and approval for researchers and others wishing to engage in any sort of research involving humans, including conducting surveys or sending out questionnaires. Such things are usually considered to be research on 
human beings, and require approval. ${ }^{11}$ Other areas in which a faculty member's academic freedom to conduct research might be restricted at some universities include cloning, especially of humans; stem cell research; abortion-related issues; research using animals; experiments involving biohazardous materials; and matters of national security and/or classified research. ${ }^{12}$

Despite such limitations, academic freedom provides for, and even anticipates, mistakes and failures. It accommodates the reality that researchers will change tactics or start over and permits faculty to experiment without fear of losing their jobs. The give and take of the classroom, including the presentation of innovative and controversial ideas, is part of academic freedom, and is particularly important to the educational process. Students learn critical thinking, and how to form and defend their own opinions, in addition to gaining substantive knowledge, when they hear a variety of approaches to a topic. Academic freedom protects the university's intellectual endeavors in all their forms. It encourages the pursuit of knowledge for knowledge's sake, and protects that pursuit.

Academic freedom is related to freedom of speech; they are not the same thing. Freedom of speech is a Constitutional right of Americans to express themselves free from governmental regulation. ${ }^{13}$ It is one of our rights as citizens, although it is subject to some restrictions, including those that may be imposed by employers. Academic freedom is not a right, but a privilege, granted by an employer to the employees. ${ }^{14}$ It covers conduct in an educational context, including the classroom, the research laboratory, and the library. Academic freedom can apply to employees of both public and private institutions and, as already noted, may come with restrictions or limitations as in other employer-granted privileges, and will come with corresponding obligations and responsibilities. The precise meaning of academic freedom differs from institution to institution. ${ }^{15}$

Academic freedom is typically granted to a university's faculty and researchers and, almost always, to its students. It is not as routinely granted to librarians or other staff members unless they are involved in teaching or research. Whether or not they have faculty status, however, academic librarians should understand how their institution has defined academic freedom. ${ }^{16}$

\section{TENURE}

A standard definition of tenure comes from the AAUP: "After the expiration of a probationary period, teachers or investigators should have 
permanent or continuous tenure, and their service should be terminated only for adequate cause, except in the case of retirement for age, or under extraordinary circumstances because of financial exigencies." 17

Tenure is a condition of employment, granted by the university to an individual faculty member, that is used both to protect and promote academic freedom and to provide enough economic security to make university teaching attractive as a profession. A tenured faculty member is given an indefinite term of appointment in return for meeting certain qualifying criteria and specified continuing performance requirements. The dismissal of a tenured professor requires cause ${ }^{18}$ and significant due process, with the involvement of multiple layers of peer review and university administration. ${ }^{19}$ Faculty without tenure, even if they are on a tenure track, are generally at-will employees whose employment can be terminated at any time. The job security of tenure is a significant guarantor of economic security.

It usually takes five to seven years for a faculty member to earn tenure. During that time, the faculty member will undergo multiple evaluations by several layers of shared governance and administration, with reappointments based on continuing assessments of the likelihood that he or she will gain tenure in the prescribed time period. Tenure usually must be granted by the governing body of the university-the board of trustees or regents, or a similar group, based on recommendations from faculty and administration.

The tenure process is intensive and demanding. Each institution establishes specific procedures for gaining tenure. Faculty must read and understand these procedures, and academic librarians should understand them, too, even if they do not have faculty status, to appreciate their impacts on faculty members. The process begins at the school or college level of the university (or department level for large universities), with unit-specific tenure procedures and peer evaluations, then moves to the campus level for another round of evaluations and administrative approvals, and finally to the board of trustees or regents.

Tenure review includes an evaluation of the candidate's teaching, scholarship, and service. Commonly, the review of teaching includes examination of student evaluations; peer evaluation, with tenured members of the faculty attending the candidate's classes; review of syllabi and course materials; and random (and anonymous) interviews of current and past students. It is typical for the evaluation committee to post a public notice inviting all students to comment on the performance of the candidate. 
The tenure candidate's research and scholarship are reviewed by faculty members at the candidate's institution and by faculty experts at other schools-usually by as many as six outside reviewers. Articles, books, chapters, and other writings are carefully scrutinized. Most tenure candidates learn early that not all scholarship or publication venues are equal, and they make an effort to write the "correct" kinds of articles and place their scholarship accordingly. For example, publication of several articles in the top law reviews is often the key to a successful tenure process. Articles in top journals (or almost any journal) are given greater weight than books, unless the book is considered significantly more scholarly than the candidate's articles. Original monographs are considered more scholarly than casebooks, which may be regarded as evidence of teaching accomplishment and not true scholarship. Newspaper opinion pieces or editorials are hardly counted unless they're in the Wall Street Journal or The New York Times. Continuing legal education articles carry little weight.

Law professors are known for in-depth and critical reviews of faculty scholarship, and the evaluation of scholarship is highly subjective. At most schools, the assessment of a tenure candidate's scholarship is by far the most important part of the process. This is one reason why law libraries are so attentive to supporting faculty research.

Service, often the "also-ran" in other types of law school evaluations, is also the "also-ran" in a tenure review. At most law schools, there is a cursory examination of whether the candidate has been a "good citizen" and has done her or his committee work, but there is little attention paid beyond that to service achievements.

The general standards for achieving tenure are described in various ways: "excellence," "outstanding achievement," "highly meritorious," and with other subjective criteria. Tenure is not granted easily, and denial of tenure will almost always require the faculty member to find employment elsewhere. For a law faculty member who has given up a lucrative job at a big firm and moved his or her family to a different state, suddenly being out of a job with few prospects elsewhere can be a stressful and humiliating experience. Other law schools may be hesitant to hire a faculty member who has already been denied tenure at another school, preferring instead to hire an entry-level candidate from the seemingly inexhaustible supply of law graduates seeking teaching positions. A tenure denial can be the end of an academic career.

Many universities use a system of post-tenure review to evaluate the performance of their tenured faculty. The process may be used for several purposes: ensuring continuing high performance of the tenured faculty, 
identifying problematic behavior and correcting it, or aiding in the growth and development of the individual faculty member's career. ${ }^{20}$ A post-tenure review is much less rigorous than a tenure evaluation. For example, most post-tenure reviews do not require outside evaluations of scholarship. Post-tenure reviews are periodic, usually at five to seven year intervals.

Academic freedom and tenure go hand in hand in fulfilling a university's mission to create and disseminate new knowledge. Once granted, the employment security offered by tenure makes it possible for faculty members to enjoy the full extent of academic freedom. Tenure shields the expression of ideas and opinions from both internal and external pressure. It allows faculty members to research controversial issues and teach disputed theories without fear of retribution by their employer. It encourages creativity, ingenuity, and independent thought by faculty members, who do not need to worry about repercussions for what may be unorthodox (but legitimate) academic pursuits. Tenure lets faculty members spend years working on highly specialized projects without worrying about finding applications for the knowledge they develop. Tenure is the strongest protection for academic freedom.

There are pressures, both within universities and from outside, to limit tenure (but not necessarily academic freedom) by creating a variety of types of non-tenure track teaching faculty. ${ }^{21}$ This frequently plays out in law schools with decisions regarding whether opportunities for tenure track appointments are made available to clinical faculty, legal writing faculty, center and institute faculty, and library directors and other library faculty, as well as to regular teaching faculty.

\section{ACADEMIC FREEDOM v. INTELLECTUAL FREEDOM}

The concept of intellectual freedom can be defined broadly and narrowly. In its broad sense, intellectual freedom encompasses the essential principles of freedom of thought, inquiry, and expression stated in Article 19 of the United Nations Universal Declaration of Human Rights: "Everyone has the right to freedom of expression; this right includes freedom to hold opinions without interference and to seek, receive and impart information and ideas through any media and regardless of frontiers." 22 Under this broader definition, which includes both freedom of expression and freedom of inquiry, academic freedom can be viewed as an application of intellectual freedom in the university setting. 
In librarianship, statements on intellectual freedom often focus more exclusively on rights of access to information than on freedom of expression. As stated by Lynn Sutton, "To a library, intellectual freedom takes the form of the right to receive ideas, that is, access to information."23 Article IV of the American Library Association (ALA) Library Bill of Rights, first issued in 1948, a few months prior to the United Nations Universal Declaration of Human Rights, emphasizes access to information and ideas, and states that "libraries should cooperate with all persons and groups concerned with resisting abridgement of free expression and free access to ideas." 24 The ALA Intellectual Freedom Principles for Academic Libraries also emphasize access and accessibility, and mention the need for confidentiality and protection of the privacy of users, but do not mention academic freedom. ${ }^{25}$ Access-based approaches to intellectual freedom provide a principled basis for the professional practices of librarians: developing collections, providing services, and offering support and information to those using the collections and services. According to Lynn Sutton, "If the librarian does not stand for intellectual freedom on campus, who will?"26

While the ALA Library Bill of Rights emphasizes access to information, the International Federation of Library Associations (IFLA) Statement on Libraries and Intellectual Freedom promotes a broader definition of intellectual freedom. The IFLA statement tracks Article 19 of the UN Declaration of Human Rights, emphasizing two aspects of intellectual freedom: both the right to know and the right to freedom of expression, each of which librarians must promote and defend:

IFLA believes that the right to know and freedom of expression are two aspects of the same principle. The right to know is a requirement for freedom of thought and conscience; freedom of thought and freedom of expression are necessary conditions for freedom of access to information. ${ }^{27}$

In promoting intellectual freedom on American university campuses, should academic librarians place more emphasis on freedom of expression? In university libraries particularly, should librarians' concerns extend beyond the traditional intellectual freedom issues of ensuring that library users have access to the information they need and protecting privacy of library users? Should the academic librarian do more than "cooperate" with those concerned with resisting abridgement of free expression on campus and become more actively involved in support 
for freedom of expression and academic freedom issues of concern to faculty and others?

\section{ACADEMIC FREEDOM ISSUES FOR LIBRARIANS}

Although usually considered in terms of university professors, the protections of academic freedom are not limited to the professoriate, but can extend to all members of the university who are involved in research and teaching. A Joint Statement on Faculty Status of College and University Librarians issued by the Association of College and Research Libraries, and endorsed by the AAUP, along with the American Association of Colleges and Universities points out, "Academic freedom . . . is indispensable to librarians, because they are trustees of knowledge with the responsibility of insuring the availability of information and ideas, no matter how controversial, so that teachers may freely teach and students may freely learn."28 Similarly, the AAUP's 2002 statement on College and University Academic and Professional Appointments states that "Professionals . . . with significant academic responsibilities should have academic freedom in the discharge of those responsibilities and in their civic lives." 29

Whether or not a university has chosen to extend the protections of academic freedom to librarians and professional staff, it is important for librarians to understand the implications of current and ongoing challenges to academic freedom, and to be able to respond to them.

\section{Attacks on Academic Freedom}

Although seemingly well established and accepted, both academic freedom and tenure are frequently under fire, often from sources claiming to promote the values of academic freedom and diversity on university campuses. An example is the Students for Academic Freedom (SAF)'s "Academic Bill of Rights," versions of which have been introduced into the legislatures of over fifteen states and into Congress. ${ }^{30}$ The Academic Bill of Rights has been highly controversial wherever it has been introduced.

Taken at face value, the language of the Academic Bill of Rights could seem to be aimed at protecting academic freedom for faculty and students. ${ }^{31}$ SAF's stated goal "is to end the political abuse of the university and to restore integrity to the academic mission as a disinterested pursuit of knowledge." 32 The organization's mission statement repeatedly cites to AAUP statements on academic freedom. Yet, it also emphasizes the 
need to make sure that professors do not indoctrinate students with their own liberal or anti-religious philosophies. According to the AAUP, "the Academic Bill of Rights undermines the very academic freedom it claims to support. It threatens to impose administrative and legislative oversight on the professional judgment of faculty, to deprive professors of the authority necessary for teaching, and to prohibit academic institutions from making the decisions that are necessary for the advancement of knowledge." 33 The ALA has also stated its opposition to "any legislation or codification of documents like the 'Academic Bill of Rights' (ABOR) that undermine academic and intellectual freedom, chill free speech, and/or otherwise interfere with the academic community's well-established norms and values of scholarship and educational excellence."34

Another organization, the American Council of Trustees and Alumni (ACTA), ${ }^{35}$ works to impose criteria to eliminate political bias in the classroom and restrict or eliminate tenure at colleges and universities. In support of its goal of promoting intellectual diversity, the ACTA Web site asks: "What happens when the intellectual freedom of politically unfashionable colleagues or students is threatened by other professors, whose outrageous behavior is itself protected by tenure and 'departmental autonomy'?... The aim is not to educate the young to think for themselves but to transform them into 'change agents' for the professor's own brand of social engineering." 36 The proposals of both SAF and ACTA have polarized politicians, academicians, and the public, causing confusion about the meaning and purposes of academic freedom and tenure, and resulting in serious questioning of their importance and necessity.

\section{Privacy and Confidentiality}

Librarians' traditional intellectual freedom concerns with privacy and confidentiality of patron records have been intensified by the ability of online library systems to create and retain records of individual computer users' uses of library materials, and, since September 11, 2001, by the invocation of national security concerns into discussions of confidentiality of library records.

The USA PATRIOT Act (Uniting and Strengthening America by Providing Appropriate Tools Required to Intercept and Obstruct Terrorism) was signed into law on October 26, 2001 and re-authorized on March 9, 2006. ${ }^{37}$ The implications of the Patriot Act for confidentiality of library records have been frequently discussed both in professional literature and in the public media. ${ }^{38}$ Reports of efforts to obtain information in library records are readily accessible through the American Library 
Association and other groups monitoring applications of the Patriot Act. ${ }^{39}$ We will not discuss the Patriot Act in detail here.

However, librarians' concerns with the Patriot Act show that, in an era when access to information through libraries entails much more than checking out books, the issues for librarians and library users extend beyond protection of circulation records. The Federal Bureau of Investigation's well-publicized 2005 attempt to use a national security letter to obtain "any and all subscriber information, billing information and access $\operatorname{logs}$ of any person" in a Connecticut library who had used a specific IP address during a particular time period demonstrates the problems of protecting access to databases and all other information accessible through library computers. ${ }^{40}$ In addition to affecting protection of records of information accessed by library users, the government's possible interests in tracking information about user interests could also affect a library's efforts to develop new electronic services such as Amazon-like applications designed to alert users to new books, articles or other sources based on what the user has previously accessed through searches or checkouts of library materials. Some observers have suggested that, despite the potential benefits of such tools for research, libraries may hesitate to develop them in order to avoid aggregating too much information about patrons. ${ }^{41}$

Confidentiality of library records is a matter of concern to academic freedom, as well as to intellectual freedom. Outside the library, other efforts to manage and monitor uses of electronic resources on university campuses should be of as much interest for their privacy implications to academic librarians as they are to others concerned with academic freedom in the university community. Recent examples include the question of whether college and university computer networks are exempted from the provisions of the Communications Assistance for Law Enforcement Act (CALEA) requiring telecommunications carriers to provide wiretapping capabilities in their networks; ${ }^{42}$ reports of Defense Department monitoring college student email communications; ${ }^{43}$ privacy of faculty e-mail communications ${ }^{44}$ and universities' continuing worries about monitoring networks in order to avoid liability for illegal file sharing of music and video. ${ }^{45}$

\section{Impacts on Research}

Since September 11, 2001, the AAUP and others monitoring academic freedom on American campuses have called attention to a range 
of issues that should be of concern to academic librarians. Many are discussed in historical context in the AAUP's 2003 report: Academic Freedom and National Security in a Time of Crisis. ${ }^{46}$

Among these issues are continuing controversies over exclusions of foreign scholars from traveling into the U.S. for conferences or to take jobs or study, on grounds that the individuals or groups have used their positions to endorse or espouse terrorism. The Academic Freedom and National Security report describes the government's interest in greater monitoring of entry into the U.S. immediately after the September 11 attacks. ${ }^{47}$ Instances in which scholars from other countries have been barred from entering the U.S. are monitored by the AAUP and reported on the International Issues in Higher Education page of the AAUP Web site. ${ }^{48}$ Widely reported examples have involved individual Bolivian, Nicaraguan, and Swiss scholars, and attempts by groups of Cuban scholars traveling to Latin American Studies Association meetings. The Commerce Department had also circulated, but eventually withdrew a proposal to tighten its rules regarding foreign-born researchers' access to sensitive technologies in their U.S. workplaces. ${ }^{49}$

The AAUP also watches the implications of government actions for scholars' abilities to freely publish or otherwise disseminate the results of their research. A 2003 ruling by the Treasury Department's Office of Foreign Assets Control (OFAC) that U.S. publishers and authors could not publish papers from authors in countries under U.S. trade embargo if any changes were made to the manuscripts, even for copyediting, without obtaining a license, ${ }^{50}$ prompted a strong reaction from the AAUP, the ALA, and such other groups as the National Coalition Against Censorship. ${ }^{51}$ The implications of the ruling, not only for publishers of scholarly journals, but for scholars engaged in collaborative projects with counterparts in countries under trade embargoes clearly implicated academic freedom. In December 2004, OFAC issued a new ruling that allowed Americans to "freely engage in most ordinary publishing activities" with several countries under trade embargo. ${ }^{52}$

\section{Restrictions on Access to Information}

The AAUP report notes that shortly after September 11, 2001, the Defense Department proposed that "scientists whose research was funded by the federal government would have to obtain prior approval from the government before publishing their work or discussing it at scientific conferences." 53 The proposal was withdrawn, but the AAUP report presents background on several areas of concern involving access to 
information, including developments regarding classified research, and the government's use of the category of "sensitive, but unclassified" information.

Because the nature of classified information is secrecy, it is difficult to know whether more federally funded research is classified now than in the past. As the report notes, however, more federal agencies now have the authority to classify information, while funding for defenserelated research programs, which are likely to require classified research, has increased significantly since September 11. The report aptly states the dilemma in these terms "The hazards of a dangerous world cannot be ignored. At the same time, secrecy, an inescapable element of classified research, is fundamentally incompatible with freedom of inquiry and freedom of expression." 54

The matter of "sensitive, but unclassified" information involves government or research information that is not classified, but is deemed too sensitive for public release without authorization. ${ }^{55}$ The device was used by government agencies prior to the terrorist attacks, but as the AAUP report points out, after September 11, federal agencies cut off public access to documents on the Internet, ordered information held in depository libraries to be withheld, and stopped providing information to the public that had routinely been made available. ${ }^{56}$ It is difficult to know what information falls into the category. In March 2006, the General Accounting Office found that federal agencies use 56 different definitions to determine whether information is "sensitive, but unclassified," and that the Department of Energy alone employed 16 definitions. ${ }^{57}$

In the university context, these are all academic freedom issues. Although some extend beyond academic librarians' traditional intellectual freedom concerns with confidentiality, they are important to librarians as well as to faculty, and call for concerted action with faculty and others.

\section{Corporatization}

The phrase "corporatization (or marketization) of the university" has been used to describe the growing influences of free market principles and other business practices on the operations of colleges and universities. ${ }^{58}$ The growth of corporate influences on university governance is seen as resulting from the increasing costs of higher education, and reductions in funding, particularly for public universities. ${ }^{59}$ The trends are leading to greater dependence on corporate sources of funding for research, and demands for universities to provide greater evidence of 
return on investment, especially from state legislatures. Perhaps as a result, there is evidence of a larger presence of business leaders on university governing boards, some of whom may think in terms of applying business efficiencies and market principles to the academy, and may see academic research as a potential source of income for resource-short universities. ${ }^{60}$ As noted by Siva Vaidhyanathan, market models consider research results to be commodities, the value of which will be increased by creating scarcity, an approach that encourages restrictions on use of information and in contracts, ${ }^{61}$ publication embargoes and prepublication reviews, and incentives for suppression of research results inconvenient to corporate sponsors. All such threats to the accessibility of information produced through university research affect academic and intellectual freedom, matters of importance both to the professoriate and librarians.

David Bollier has written eloquently about the potential effects of market thinking on the basic operations of the university. ${ }^{62}$ Bollier describes the ways in which market analogies directly contradict the operations of the scholarly (or academic) commons, noting that, although market terminology dominates contemporary discussions of wealth creation, the market is not the only way in which wealth or value can be created. In academia, he argues, the more appropriate model is that of the commons. ${ }^{63}$ In the commons, value is created not by creating scarcity, but through sharing and collaboration:

Science and academia are, at bottom, gift economies. They are communities held together by shared moral, social and intellectual commitments. Their members give, get, share and collaborate with each other without the vast apparatus of market exchange. Interactions are not generally governed by property rights, legal contracts, and fees. ${ }^{64}$

In the gift economies of the scholarly commons, the results of scholarship are made openly available and accessible to others for evaluation and development, possibilities that are enlarged by the ease of communication and sharing outside the physical boundaries of the campus by the Internet. Understanding the nature of the scholarly commons underscores the importance of the library community's commitment and encouragement to open access initiatives in order to support and strengthen the gift economy. ${ }^{65}$

The possible impacts of corporatization on the operating mechanisms of the university raise issues of academic and intellectual freedom for 
librarians and other members of the academic commons. More generally, they also bring to mind Cass Sunstein's point regarding the value of public spaces (virtual and physical) in a democratic order. ${ }^{66}$ In the academy, common spaces such as the library must be preserved as the role of the university is threatened with external changes, and as technology affects how teaching and learning take place within the university.

\section{Content and Format Selection}

Traditional library concerns with censorship, banned books, and restrictions on what can be purchased are issues of academic freedom as well as intellectual freedom. Instances are always easy to find. Not long after the September 11 attacks, the proposed assignment of a book about the Koran as a summer reading assignment for incoming freshmen at the University of North Carolina at Chapel Hill was challenged in court as being overly sympathetic to Islam, and legislation requiring equal time for the study of all religions was introduced into the state legislature. ${ }^{67}$ In April 2006, there was controversy at the campus of Ohio State-Mansfield over a librarian's recommendation of several conservative best sellers as reading for a first-year reading experience course. ${ }^{68}$ In June 2006, the dean of libraries at the University of the Incarnate Word in San Antonio, Texas temporarily cancelled the library copy of the The New York Times in protest over a Times article describing a federal government program to monitor international cash transfers by suspected terrorists. ${ }^{69}$

Questions of what should be purchased by university libraries, as well as the intellectual and academic freedom issues that often accompany controversial purchase decisions, can be expected to increase as funding for library purchases, particularly of print resources, continue to dwindle. ${ }^{70}$ But, is academic freedom implicated by librarians' decisions regarding choices of format, as well as by choices of content? In particular, do decisions to purchase materials in electronic formats rather than print, or attempts to rely entirely on digital libraries, ${ }^{71}$ raise academic freedom issues?

In a May 2006 New York Times Magazine article titled, "Scan this Book!,"72 founding executive editor of Wired magazine, Kevin Kelly envisioned a quick arrival for a universal digital library resulting from projects by Google and others to scan the world's libraries and make the contents available via the Web. In addition to improved access to information and other benefits of the universal digital library, Kelly saw significant value in readers' forthcoming abilities to "unravel" digital 
books into single pages or even snippets of pages, which could be re-mixed and reordered according to individual tastes and interests into new books or other forms, just as samples of songs can be re-mixed into new pieces of music. The following month, author John Updike responded to Kelly's idea in The New York Times Book Review, ${ }^{73}$ asking whether reliance on "teeming, promiscuous uncredited word snippets" did not deprive the written word of its function of promoting accountability and intimacy between author and reader. Updike commented, "The printed, bound and paid-for book was-still is, for the momentmore exacting, more demanding, of its producer and consumer both. It is the site of an encounter, in silence, of two minds, one following in the other's steps but invited to imagine, to argue, to concur on a level of reflection beyond that of personal encounter . .."74

In some ways, Updike's comments echoed those made in a 2005 article $^{75}$ by S. David Mash, dean of information resources and services at Columbia International University. Mash wrote about current criticisms of the book as promoting linear thinking and ways of thought that often force us to think in "ways that require narrowness, decontextualization, and intellectual attenuation, if not downright impoverishment." 76 Mash responded to these criticisms by questioning the impacts of technological determinism on educational thinking, in particular higher education's rush to use new tools simply because they are there, and the idea that, because students are habituated to certain ways of learning and accessing information, educators should embrace them as well.

Arguing for the importance of encouraging students to develop awareness of alternative ways of thinking to those with which they are already comfortable, Mash wrote:

The systematic de-emphasis of print media and the unique habits of mind they alone inculcate suppresses the spirit of inquiry because it foreshortens the horizon of ideas to which a student may be exposed and narrows the cognitive options for developing and exploring alternative ways of thinking.

Administrative decisions that misappropriate the role of books by marginalizing their presence deprive students of a means of inquiry and intellectual growth with attributes and effects all its own and necessary for the sustenance of a balanced and considered life of the mind. ${ }^{77}$ 
For Mash, a decision to exile books "with unique content found only offline is a depredation of academic freedom, an indirect and unintentional, but potent act of censorship."78

\section{CONCLUSION}

The profession of librarianship has long dedicated itself to protecting the rights of information seekers to search for and to receive information from all sources, as well as to preserving the confidentiality of information gathered about library users. In the university, librarians should be familiar not only with the concerns of intellectual freedom, but with the role of academic freedom in the life of the scholarly community. Intellectual freedom and academic freedom are linked, but are not identical. It is essential for academic librarians to understand the differences between the concepts and the importance of academic freedom and tenure to faculty, students and others involved in teaching and research. In a time of rapidly changing technologies, financial exigencies, and new government information policies aimed at protecting national security, challenges to academic freedom will impact university libraries just as much as they will the other parts of the university. Librarians will need to bring their skills and talents to bear in resolving these issues in active collaboration with others in the university community. Gaining familiarity with the documents of academic freedom and the organizations dedicated to its protection, such as the AAUP, are necessary first steps to taking on these important professional tasks.

\section{NOTES}

1. A recent example is the controversy regarding University of Colorado professor Ward Churchill's comments regarding the victims of the September 11, 2001 attacks on the World Trade Center. In an essay written shortly after the attacks, Professor Churchill compared some World Trade Center workers to Nazi war criminal Adolf Eichmann. In July 2006, following the report of an investigative panel that found research misconduct in his work, the University began a process to dismiss Churchill. See Scott Smallwood, U. of Colorado Begins Process to Fire Ward Churchill, Chron. Higher Ed., July 7, 2006, at A12. Professor Bintliff was chair of the University of Colorado at Boulder Faculty Assembly from 2003 to 2005.

2. See American Association of University Professors, 1940 Statement of Principles on Academic Freedom and Tenure with 1970 Interpretive Comments, available at 
http://www.aaup.org/AAUP/pubres/policydocs/1940statement.htm. [AAUP Statement (1940)]. The AAUP Statement has been endorsed by a long list of learned and professional societies, including the American Library Association and the Association of American Law Schools. The list can be found at http://www.aaup.org/AAUP/pubres/policydocs/ endorsersalpha.htm (last visited August 24, 2006). The statement has not been endorsed by the American Association of Law Libraries.

3. Extramural speech includes comments made by academics as citizens, outside their teaching and research roles within the academy.

4. AAUP Statement (1940), supra n. 2.

5. Alex Byrne, "See Librarian": University Libraries and Intellectual Freedoms, 30 Australian Acad. \& Res. Libr. 107, 107 (1999).

6. For example, Academic Freedom at Brigham Young University (April 1, 1993) (copy on file with Professor Bintliff ). The summary of this document states:

At BYU, individual academic freedom is based not only on a belief (shared by all universities) in the value of free inquiry, but also on the gospel principle that humans are moral agents who should seek knowledge in the sacred as well as in the secular, by the heart and spirit as well as by the mind, and in continuing revelation as well as in the written word of God. BYU students and their parents are entitled to expect an educational experience that reflects this aspiration.

7. AAUP Statement (1940). A 1970 interpretive comment to the AAUP Statement says: "Most church-related institutions no longer need or desire the departure from the principle of academic freedom implied in the 1940 Statement, and we do not now endorse such a departure." Id. The AAUP does not accredit or regulate institutions of higher education; its statements are guidelines only.

8. University of Colorado Board of Regents, Laws of the Regents, Art. 5.D.2. (A), available at https://www.cu.edu/regents/Laws/Article5D.htm (last visited June 12, 2007).

9. Id. Compare with Duke University Faculty Handbook, Appendix C, Academic Freedom and Tenure, sec. I.A. (2004), available at http://www.provost.duke.edu/pdfs/ fhb/FHB_App_C.pdf.

10. See University of Washington, A Statement of Principle: Academic Freedom and Responsibility, sec. 24-33, available at www.washington.edu/faculty/facsenate/ handbook/Volume2.html (last visited August 24, 2006).

11. For example, University of Colorado at Boulder, Office of the Vice Chancellor for Research, Human Research Committee, available at http://www.colorado.edu/ VCResearch/HRC/background.html (last visited August 24, 2006).

12. For example, University of North Carolina-Chapel Hill, UNC-Chapel Hill Policy on Use of Human Embryonic Stem Cells in Research, available at http://research. unc.edu/services/stem_cells.php\#statement (last visited August 24, 2006); Stanford University, Research Policy Handbook, Biohazardous Agents and Recombinant DNA (RPH 6.9), available at http://www.stanford.edu/dept/EHS/prod/aboutus/documents/ policyrph6_9.html (last visited August 24, 2006).

13. U.S. Const. amend I.

14. The US Supreme Court has held that academic freedom is a "special concern" of the First Amendment, but it has not declared it a First Amendment right, per se. See Sweezy v. New Hampshire, 354 U.S. 234 (1957); Keyishian v. Board of Regents, 385 U.S. 589 (1967); Regents of Univ. of Michigan v. Ewing, 474 U.S. 214 (1985); Univ. of Wisconsin v. Southworth, 529 U.S. 217 (2000). The circuits are split. See J. Peter 
Byrne, Academic Freedom: A "Special Concern" of the First Amendment, 99 Yale L.J. 251 (1989).

15. The University of Colorado Board of Regents defines academic freedom "as the freedom to inquire, discover, publish and teach truth as the faculty member sees it, subject to no control or authority save the control and authority of the rational methods by which truth is established." University of Colorado Board of Regents, Laws of the Regents, Art. 5.D.1.(B), supra n. 8. Duke University's definition of academic freedom includes three elements, which generally track the AAUP definition:

I. Academic Freedom

A. To teach and to discuss in his or her classes any aspect of a topic pertinent to the understanding of the subject matter of the course being taught.

B. To carry on research and publish the results subject to the adequate performance of his or her other academic duties.

C. To act and to speak in his or her capacity as a citizen without institutional censorship or discipline.

Duke University Faculty Handbook, Appendix C., supra n. 9.

16. The university's statement should be available on the institution's Web site under any of a number of labels, for example, intellectual freedom, faculty freedom, academic freedom, or rights, and responsibilities of faculty. Some universities restrict these documents to current employees, requiring a password or university identification of some sort to gain access to the information.

17. AAUP Statement (1940), supra n. 2.

18. The AAUP does not specify cause for dismissal beyond stating that a faculty member should be terminated for "adequate cause, except in the case of retirement age, or . . financial exigencies." Id. Instead, the AAUP recommends that " $[\mathrm{t}]$ he precise terms and conditions of every appointment should be stated in writing and be in the possession of both institution and teacher before the appointment is consummated." Id. One example of enumerated causes for dismissal comes from the University of Colorado System:

The grounds for dismissal shall be demonstrable professional incompetence, neglect of duty, insubordination, conviction of a felony or any offense involving moral turpitude upon a plea or verdict of guilty or following a plea of nolo contendere, or sexual harassment or other conduct which falls below minimum standards of professional integrity. University of Colorado Board of Regents, Laws of the Regents, Art. 5.C.1., supra n. 8.

19. For recommended procedural guidelines in faculty dismissal cases, see American Association of University Professors, AAUP Statement on Procedural Standards in Faculty Dismissal Proceedings, available at http://www.aaup.org/AAUP/pubres/policydocs/ statementon+proceduralstandardsinfaculty+dismissal+proceedings.htm (last visited August 24, 2006). Most universities have less-complete procedures for the termination of a non-tenured faculty member than for a tenured professor.

20. See Joan North, Post-Tenure Review: Rehabilitation or Enrichment? 51 AAHE Bulletin (no. 8, April 1999), available at http://www.uwsp.edu/CPS/Staff/jnorth/ Documents/AAHEBulletin-0499.htm. 
21. For example., Matthew W. Finkin, The Campaign Against Tenure, Academe, May-June 2000, at 20 (discussing impacts of post-tenure reviews and contingent appointments).

22. See Universal Declaration of Human Rights, Art. 19 (1948), available at http:// www.un.org/Overview/rights.html.

23. Lynn Sutton, Advocacy for Intellectual Freedom in an Academic Library, in Crossing the Divide: Proceedings of the ACRL 10th National Conference 54, 54 (2001).

24. American Library Association, Library Bill of Rights (1948), available at http:// www.ala.org/ala/oif/statementspols/statementsif/librarybillofrights.pdf (emphasis added).

25. American Library Association, Intellectual Freedom Principles for Academic Libraries: An Interpretation of the Library Bill of Rights (2000), available at http:// www.ala.org/ala/oif/statementspols/statementsif/interpretations/ifprinciplesacademic libraries.pdf. The American Association of Law Libraries has no statement on academic or intellectual freedom, although AALL's Government Relations Policy states that: "AALL endorses the Library Bill of Rights ... and supports the right of libraries to disseminate materials on all subjects. The Association vigorously opposes censorship. Similarly, AALL supports nondiscriminatory access to information for all library users." AALL Government Relations Policy (2001), available at http://www.aallnet.org/ about/policy_government.asp.

26. Sutton, supra note 23 , at 56.

27. International Federation of Library Associations, Statement on Libraries and Intellectual Freedom (1999), available at http://www.ifla.org/faife/policy/iflastat/iflastat. htm.

28. See Joint Statement on Faculty Status of College and University Librarians (1972), available at http://www.ala.org/ala/acrl/acrlstandards/jointstatementfaculty.htm.

29. See College and University Academic and Professional Appointments (2002), available at http://www.aaup2.org/statements/REPORTS/ProfessionalAppt.htm (last visited June 12, 2007).

30. Information about Students for Academic Freedom, and links to the bills introduced into Congress and state legislatures can be found at http://www. studentsforacademicfreedom.org/ (last visited August 24, 2006). The Web site's subtitle is: "You can't get a good education if they are only telling you half the story."

31. Academic Bill of Rights, http://www.studentsforacademicfreedom.org/abor. html (last visited August 24, 2006).

32. See Students for Academic Freedom, About SAF, http://cms.studentsforacademic freedom.org//index.php?option=com_content\&task=view\&id=2\&Itemid=5.

33. See Academic Bill of Rights (statement by the AAUP Committee A on Academic Freedom and Tenure), http://www.aaup.org/AAUP/About/committees/committe+repts/ crisistime.htm (last visited August 24, 2006).

34. American Library Association, Resolution in Support of Academic Freedom (January 25, 2006), http://www.ala.org/ala/oif/statementspols/ifresolutions/academic freedom.htm.

35. See American Council of Trustees and Alumni, http://www.goacta.org (last visited August 24, 2006).

36. American Council of Trustees and Alumni, Academic Freedom, http://www. goacta.org/issues/academic_freedom.html (last visited August 24, 2006).

37. Uniting and Strengthening America by Providing Appropriate Tools Required to Intercept and Obstruct Terrorism (USA PATRIOT ACT) of 2001, Pub L. No. 
107-56, 115 Stat. 272 (October 26, 2001) [hereinafter cited as USA Patriot Act]; see also USA PATRIOT Improvement and Reauthorization Act of 2005, Pub. L. No. 109-177, 120 Stat. 192 (March 9, 2006).

38. For example., David Rogers, "We're From the Government and We're Here to Help You”: Libraries and the USA Patriot Act, 6 Legal Info. Mgmt. 55 (2006); Susan Nevelow Mart, Protecting the Lady from Toledo: Post-USA PATRIOT Act Electronic Surveillance at the Library, 96 Law Libr. J. 449 (2004).

39. For example, American Library Association, USA PATRIOT Act and Intellectual Freedom, http://www.ala.org/ala/oif/ifissues/usapatriotact.htm (last visited August 24, 2006); Electronic Freedom Foundation, The USA PATRIOT Act, http:// www.eff.org/patriot/ (last visited August 24, 2006).

40. Letter of May 19, 2005 from Michael J. Wolf, FBI Special Agent in Charge, to Kenneth Sutton, Systems and Telecommunication Manager, Library Connection, Inc. See also Andrea L. Foster, Federal Government Abandons Fight for Connecticut Library Group's Records, Chron. Higher Ed. July 7, 2006, at A34. For an expression of student concerns, see Maya Rao, USA Patriot Affects Cornell U.'s Libraries, Cornell Daily Sun, March 14, 2006, available at http://cornellsun.com/node/17053.

41. For example, Editorial: Patriot Act may start to impede more than liberties, Daily Bruin (UCLA), November 21, 2005, available at http://www.dailybruin.ucla. edu/news/2005/nov/21/editorial-patriot-act-may-star/.

42. See Andrea Foster, Officials Predict Colleges Will Be Exempt from Ruling on Network Surveillance, Chron. Higher Ed., July 28, 2006, at A24.

43. See Samantha Henig, Pentagon Surveillance of Student Groups Extended to Scrutinizing E-Mail, Chron. Higher Ed., July 21, 2006, at A21.

44. See Robert M. O’Neil, Who Owns Professors' E-Mail Messages? Chron. Higher Ed., June 25, 2004, at B9.

45. For example, Brock Read, Entertainment Industries Ask Colleges to Monitor Local Networks for Piracy, Chron. Higher Ed., May 12, 2006, at A39; Brock Read, Lawmakers Will Seek a Federal Study of Campus Policies on File Swapping, Chron. Higher Ed., October 7, 2005, at A38.

46. Academic Freedom and National Security in a Time of Crisis: Report of the AAUP's Special Committee, Academe, November-December 2003, at 34. [hereinafter cited as Academic Freedom and National Security], available at http://www.aaup.org/ AAUP/About/committees/committe+repts/crisistime.htm.

47. Id. at 48-51.

48. American Association of University Professors, International Policy Issues, Freedom to Travel, http://www.aaup.org/Issues/international/Policy/travel.htm (last visited August 24, 2006).

49. See Kelly Field, Proposal to License Scholars Is Pulled, Chron. Higher Ed., June 9,2006 , at A24.

50. See Marjorie J. Censer, Government Scrutinizes Scholarly Publishing, Academe, Sept.-Oct. 2004, at 5. The OFAC ruling considered copyediting to be an act providing a service to the author in the country under the trade embargo, thereby violating the embargo.

51. See Statement in Opposition to the Embargo of Intellectual, Scientific, and Literary Works (April 12, 2004), http://www.aaup2.org/statements/SpchState/Statements/ CoalAgainstCenpet.htm (last visited June 12, 2007). This statement seems no longer to be available through the public AAUP web site (http://www.aaup.org/aaup). 
52. See Treasury Issues General License for Publishing Activities (December 15, 2004), http://www.treas.gov/press/releases/js2152.htm.

53. Academic Freedom and National Security, supra note 46, at 42.

54. Id. at 43.

55. Id. at 46-48. See also Genevieve J. Knezo, "Sensitive But Unclassified" Information and Other Controls: Policy and Options for Scientific and Technical Information (February 15, 2006) (CRS), available at http://www.fas.org/sgp/crs/secrecy/RL 33303.pdf.

56. Academic Freedom and National Security, supra note 46, at 43.

57. U.S. Government Accountability Office, Managing Sensitive Information: Departments of Energy and Defense Policies and Oversight Could Be Improved (March 2006) (GAO-06-369).

58. See James G. Andrews, How We Can Resist Corporatization, Academe, May-June 2006, at 16.

59. See generally, Ronald G. Ehrenberg \& Michael J. Rizzo, Financial Forces and the Future of American Higher Education, Academe, July-August 2004, at 28.

60. Applications of corporate and market thinking to the university were seen by some observers in the May 26, 2006 draft report to the Secretary of Education by the Commission of the Future of Higher Education, which criticized American universities for institutional inefficiencies and failures to make better use of technology to control costs. For reaction to the initial draft report, see Mark F. Smith, Government Relations: I've Seen the Future, Academe, May-June 2006, at 111. Reactions to revised drafts of the report were less critical. See, e.g., Kelly Field, Revised Report by Federal Commission Offers Milder Critique of Colleges, Chron. Higher Ed., July 28, 2006, at A15. See generally, Sam Dillon, Federal Panel Hammers Out Report on Recommendations to Shake Up Higher Education, NY Times, August 11, 2006, at A11. For the reports and other information about the Commission, see A National Dialogue: The Secretary of Education's Commission on the Future of Higher Education, http://www.ed.gov/ about/bdscomm/list/hiedfuture/index.html (last visited August 24, 2006).

61. See Siva Vaidhyanathan, The Content-Provider Paradox: Universities in the Information Ecosystem, Academe, September-October 2002, at 34, 37.

62. See David Bollier, The Enclosure of the Academic Commons, Academe, September-October 2002, at 18; Defending the Scholarly Commons (November 16, 2004) (Remarks of David Bollier at Georgetown University) [hereinafter Bollier (2004)], available at http://www.bollier.org/pdf/GeorgetownUremarksNov2004.pdf.

63. Bollier (2004), supra note 62 at 5.

64. Id. at 6.

65. For a short introduction to open access and a list of resources, see Heather Morrison, Open Access for Librarians in Developing Countries (2006), available at http:// ir.lib.sfu.ca/retrieve/2641/OADeveloping.pdf.

66. Cass Sunstein, Freedom of Expression in the United States: The Future, in Thomas R. Hensley, ed., The Boundaries of Freedom of Expression and Order in American Democracy 319, 319 (2001).

67. See Academic Freedom and National Security, supra note 46, at 54.

68. See Librarian's Book Choice Sparks Controversy at Ohio State's Mansfield Campus, Library Journal Academic Newswire, April 20, 2006, http://www.libraryjournal. com/clear/CA6326622.html.

69. See Melissa Ludwig, Incarnate Word Cancels NY Times Subscription Over Story, San Antonio Express News, June 29, 2006, available at http://www.mysanantonio.com/ 
news/educaion/stoies/MYSA062906.nytimes.EN.bbc4a6b.html. The subscription was reinstated after two days. See Melissa Ludwig, NY Times is Back at College-For Now, San Antonio Express News, July 3, 2006, available at http://www.mysanantonio.com/ news/educaion/stoies/MYSA070106.01A.UIW.16614e4.html.

70. Barbara Jones, The Academic Aspects of Intellectual Freedom, Am. Libr., June/July 1999, at 80.

71. For example, Scott Carlson, Library Renovation Leads to Soul Searching at Cal Poly, Chron. Higher Ed., September 1, 2006, at A59.

72. Kevin Kelly, Scan this Book!, The New York Times Magazine, May 14, 2006, at 43.

73. John Updike, Essay: The End of Authorship, The New York Times Book Review, June 25, 2006, at 27.

74. Id.

75. S. David Mash, Libraries, Books, and Academic Freedom, Academe, May-June 2003 , at 50 .

76. $I d$. at 52 .

77. Id. at 54 .

78. Id. (emphasis added).

Received and Accepted: 08/30/06 doi:10.1300/J113v25n04_03 